\title{
Estimation of Runoff Unit Area Loads for Nutrients from Forest and Sloping Field using SWAT model in Bonggok Stream Watershed
}

\section{SWAT모형을 이용한 봉곡천 유역 경사지밭, 산지의 영양염류 배출 원단위 산정}

\author{
Kim, Ki-Yun* ${ }^{*}$ Ryu, Byong-Ro ${ }^{* *} \cdot$ Lee, Kyu-Seung ${ }^{* * *} \cdot$ Moon, Jongpil $^{* * * *,+}$ \\ 김기운 · 유병로 · 이규승 · 문종필
}

\begin{abstract}
본 연구에서는 2005년부터 2006년까지 충청남도 공주시 반포면에 위치한 봉곡천 유역의 경사지 밭을 포함하고 있는 산지하천에서 유출량, 총인, 총질소를 측정하였고 측정된 자료는 SWAT 모형을 통하여 장기간의 배출부하량 산정을 위해 모형의 보정 및 검정자료로 사용하였다. SWAT 모형의 보정 및 검정결과는 유출량은 일별자료를 이용하여 보정 및 검정을 실시하였다. 그 결과 결정계수 $\left(\mathrm{R}^{2}\right)$ 가 $0.80 \sim 0.83$ 의 값을 보였으며 일별 T-N, T-P 부하량에 대한 보정 및 검정결과는 결정계수 $\left(\mathrm{R}^{2}\right)$ 가 $0.62 \sim 0.86$ 의 값을 보였다. 모형의 보 정 및 검정을 통해 결정된 최적매개변수를 적용하여 1997년부터 2006년까지 관측된 강우자료로 장기간의 유출량, T-N, T-P 배출부하 량에 대한 SWAT 모형 시뮬레이션을 수행하였다. 또한 이를 바탕으로 하여 산지와 밭에 대한 원단위를 산정하였으며, 그 결과 산지에 대한 T-N의 원단위는 $3.29 \mathrm{~kg} / \mathrm{km}^{2} /$ day이었고 T-P에 대한 원단위는 $0.15 \mathrm{~kg} / \mathrm{km}^{2} / \mathrm{day}$ 로 나타났다. 또한 밭에서의 T-N에 대한 원단위는 $11.15 \mathrm{~kg} / \mathrm{km} / \mathrm{day}$ 이었고 T-P에 대한 원단위는 $0.70 \mathrm{~kg} / \mathrm{km}^{2} / \mathrm{day}$ 로 나타났으며 강우의 시간 및 공간적 변화에 따른 유출량을 고려한 산 지와 밭에서의 영양염류 배출부하량을 산정하는데 SWAT모형을 적용하는 것이 타당성이 있는 것으로 판단되었다.
\end{abstract}

Keywords: SWAT model; T-N; T-P; Unit area load; Sloping Field; Forest

\section{INTRODUCTION}

Importance of controlling of nonpoint source pollutants has been recognized in recent years because policies were implemented focusing mainly on point source pollutants and water quality has not been improved as expected. A research on land use regarding nonpoint source pollutants and nation-wide pollution contribution degree were conducted for the first time in 1994. Lee et al. (1998) examined the amount of soil loss and used it as a basic data for

* Researcher, Division of Civil, Environment and Urban Engineering, Hanbat National University, Daejeon, South Korea

** Proffessor, Division of Civil, Environment and Urban Engineering, Hanbat National University, Daejeon, South Korea

*** Proffessor, Department of Bio Environmental Chemistry, Chungnam National University, Daejeon, South Korea

**** Researcher, Department of Agricluturalt Engineering, National Academy of Agricultural Science, Suwon, South Korea

$\dagger \quad$ Corresponding author Tel.: +82-31-031-1823

Fax: +82-31-031-1823

E-mail: jpmoon2002@korea.kr

2012년 2월 23일 투고

2012년 3월 21일 심사완료

2012년 3월 22일 게재확정 comprehensive conservation and management for soil and water resources. Jung et al. (1976) examined the amount of soil and nutrients loss in sloping area and conducted a research on soil loss prediction and classifying nutrient loss conditions. In addition, Yoon et al. (2001) analyzed discharge characteristics of nonpoint source pollutants by characteristics of land use. "Nationwide nonpoint source pollutants research project" conducted by Ministry of Environment in 1995 established the unit area loads of nonpoint source pollutants in areas such as city, paddy field, crop field, forest and pasture, and requested to estimate the amount of nonpoint source pollutants. Consequently, the contribution of nationwide nonpoint source pollutants was examined, which led to the introduction of various measures for nonpoint source pollutants in 'Water management comprehensive measure' in 1997 and the 'Special comprehensive measure for water quality improvement of Paldang waterworks such as Han river' in 1998.

Nonpoint source pollutants discharges are closely related to precipitation and there is large variation in daily, and seasonally along with land use and slope. 
The objectives of this study were to calibrate and validate the SWAT model with measured data and estimate pollutant runoff unit loads for each land use. For these ends, measured discharge and water quality data were collected at BonggokRi, Banpo-Myeon, Gongju City.

\section{METHODS AND MATERIALS}

\section{Study Area and Data Survey}

\section{A. Study area}

Bonggok-Ri watershed (Area : $0.34 \mathrm{~km}^{2}$ ) is located in Banpo-Myeon, Gongju City, Republic of Korea with characteristics of farmland's continuous pollutants discharge. As for selection criteria, in the case of mountainous area, in the range of continuous water utilization movement, areas were selected, and areas of $3^{\circ} \sim 5^{\circ}$ variation of vegetation and slope on the same line were selected. In the case of

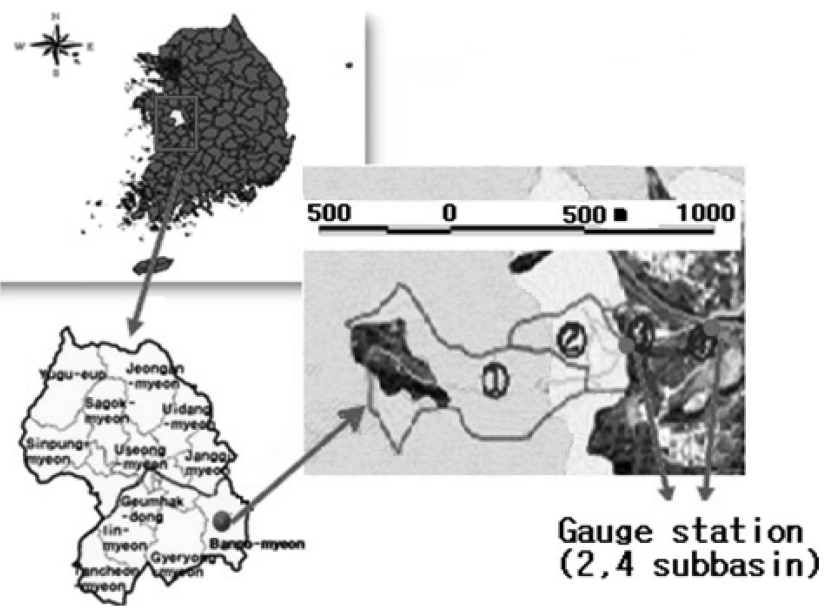

Fig. 1 Experimental watershed map cropland (field) areas where flow water from forest area are transmitted directly and areas that are not affected by flow water were selected as controlled group and in the case of crop land (field), out of non-affected area from forest area, two regions were selected respectively.

A. Water flow and water quality survey

(1) Survey period

When it rains and when it is clear, measuring water flow amount and water quality were conducted at the same outlet from 2005 to 2006, and survey was conducted in two outlets (2), (4) outlet) within watershed where measurement is easy. Pressure-type flowrate gauging instrument was also used to measure flowrate.

(2) Landuse

Characteristics of watershed landuse is that forest was the 1,2 subbasin's representative landuse and sloping cropland (field) was that for 3, 4 subbasin hence forest's runoff and nutrient loads were measured at outlet 2 and runoff and nutrient loads were also meaured at 4 outlets and then calculated runoff, nutrient loads for cropland by subtracting the measured vaule at outlet 2 from the measured at outlet 4 .

\section{Application of SWAT Model}

\section{A. Input data}

For performing SWAT model simulation in study area, Rural Development Administration's 1:25,000 precise soil map were used as Fig. 2(c) and 1:25,000 landcover (middle classification)map issued from Environmental Geographic

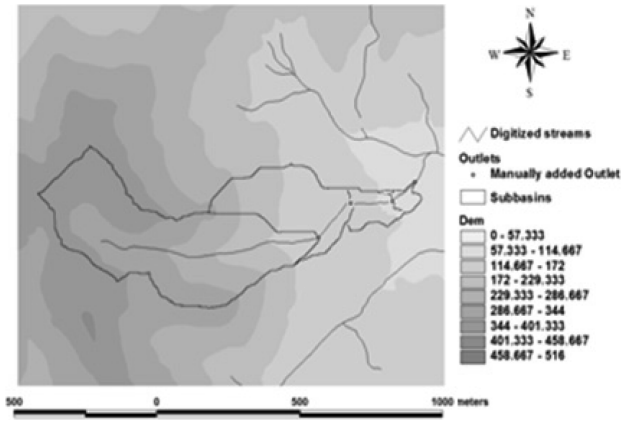

(a) DEM and River

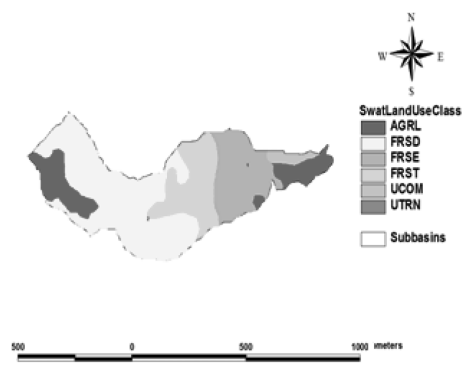

(b) LANDCOVER $(1: 25,000)$

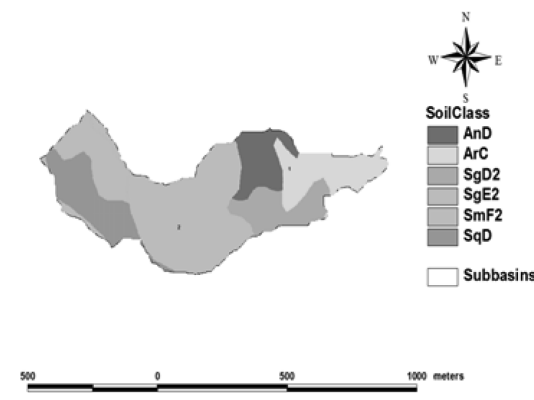

(c) SOIL $(1: 25,000)$

Fig. 2 GIS input data for SWAT model 
Information System (EGIS) was used as Fig. 2(b). Digital Elevation Model (DEM) was rebulited from 1:25,000 topographical map.

Solar radiation, rainfall, relative humidity, highest/lowest temperature, wind speed were builted, in the 5 files, location information of two weather station (Daejeon, Banpo).

\section{B. Evaluation method of model implementation result}

As a method for evaluation of model simulation results, coefficient of determination $\left(\mathrm{R}^{2}\right)$ value of regression analysis was applied.

\section{RESULTS AND DISCUSSION}

\section{Calibration and Validation}

\section{A. Calibration of model}

(1) Runoff calibration

(a) Parameter calibration

In this study, simple and widely used simple trial and error method was used even though it takes time. The calibration of model was calibrated using runoff amount measured at the 2, 4 outlet point of applied watershed in 2005. As for criteria for model's calibration, it was estimated with coefficient of determination through regression analysis

(b) Runoff amount calibration

For calibration of runoff discharge, this research calibrated by selecting parameters using calibration tool provided by SWAT model itself. As a result, $\mathrm{CN}_{2}$ increased 8 vaule as
Table 1 Runoff parameter and calibrated values

\begin{tabular}{c|c|c}
\hline Input file & Parameter & Calibrated value \\
\hline \hline$*$ mgt & $\mathrm{CN}_{2}$ (Curve number) & $\triangle 8$ \\
\hline
\end{tabular}

Table 2 Coefficient of determination of runoff amount by outlet

\begin{tabular}{c|c|c}
\hline Classification & Outlet 2 & Outlet 4 \\
\hline \hline Coefficient of Determination $\left(\mathrm{R}^{2}\right)$ & 0.80 & 0.83 \\
\hline
\end{tabular}

shown in Table 1 below.

Fig. 3 and Fig. 4 show changes in observed and simulated values according to 2005 rainfall, the correction period, and as the figures show, calibration values were relatively well optimized in proximity to the observed value.

\section{(2) Calibration of nutrients}

This study calibrated values by selecting parameters using calibration tool provided by SWAT model itself. As a result, Nitrate percolation coefficient (NPERCO) was increased by 0.3, NPERCO parameter controls the amount of nitrate removed from the surface layer in runoff relative to the amount removed via percolation. The phosphorus percolation coefficient (PPERCO) parameter is the ratio of the solution phosphorus concentration in the surface $10 \mathrm{~mm}$ of soil to the concentration of phosphorus in percolate. In this study area, PPERCO was set to 10 . Phosphorus soil partitioning coefficient (PHOSKD) is the ratio of the soluble phosphorus concentration in the surface $10 \mathrm{~mm}$ of soil to the concentration of soluble phosphorus

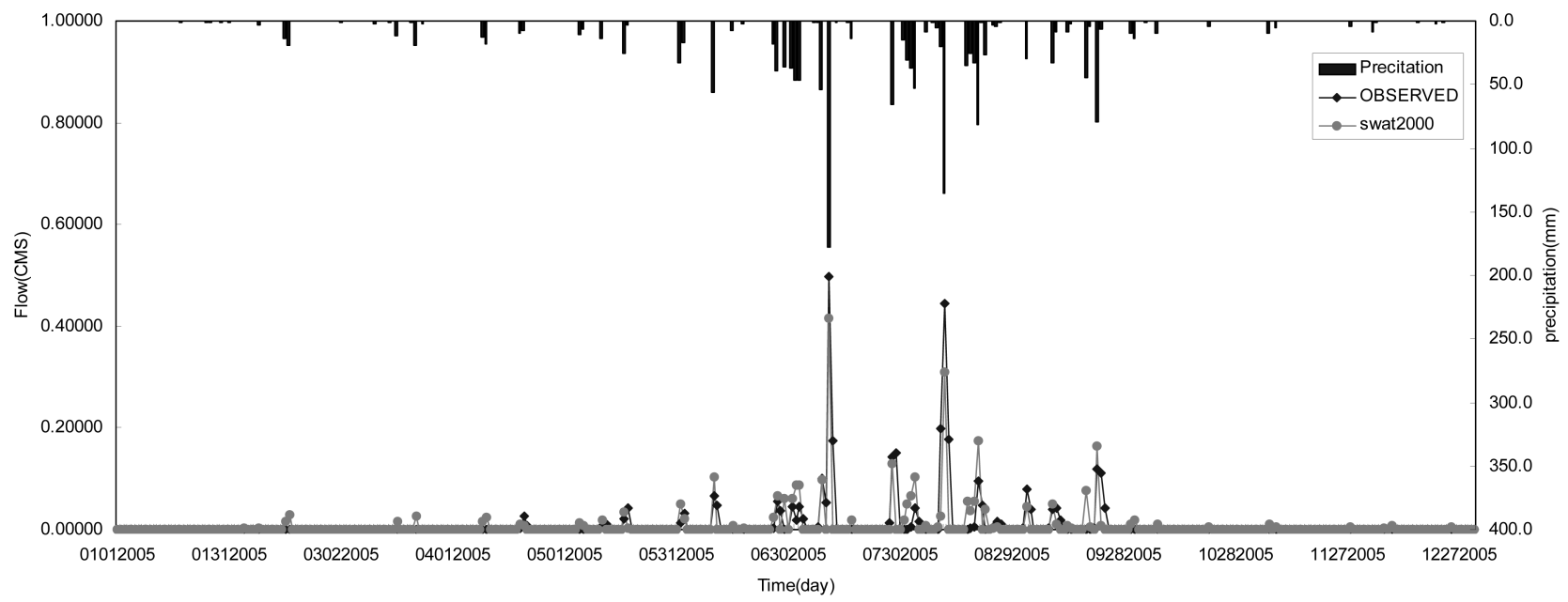

Fig. 3 Simulated and observed values of runoff flowrate on daily base (outlet 2) 


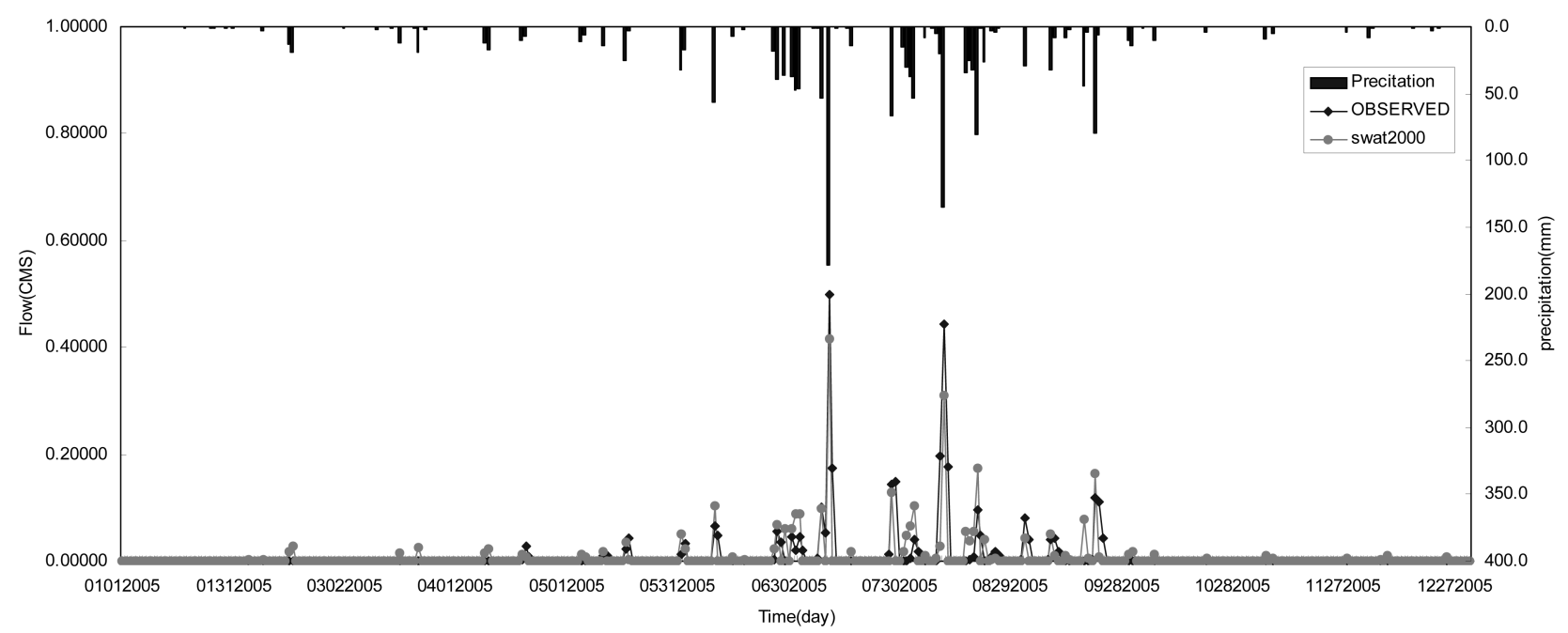

Fig. 4 Simulated and observed values of runoff flowrate on daily base (outlet 4)

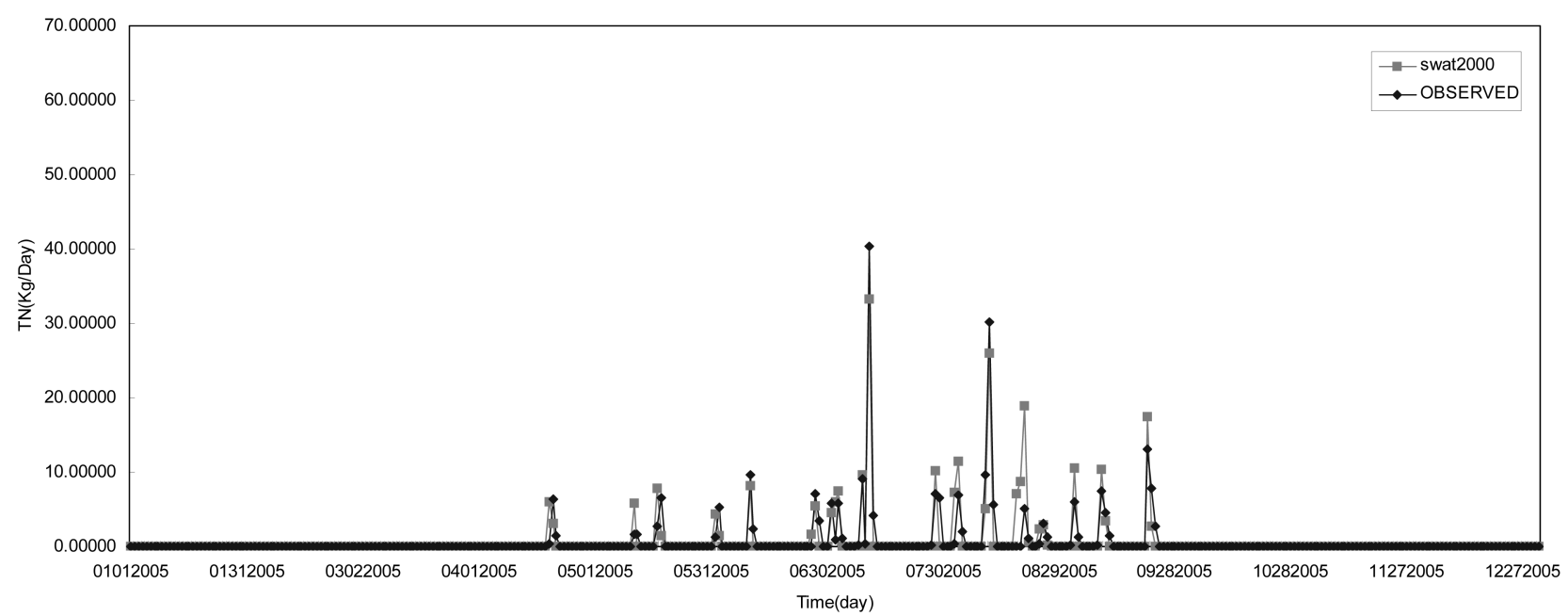

Fig. 5 T-N Simulated and observed values at outlet 2

in surface runoff and PHOSKD was set to 180. Initial soluble P concentration in soil layer (SOL_SOLP) was also very important parameter in nutrients runoff and it was set to 0.05 . Initial $\mathrm{NO}_{3}$ concentration in the soil layer $\left(\mathrm{SOL} \_\mathrm{NO}_{3}\right)$ was set to 0.01

Table 3 shows parameters that are used for calibrating total phosphorus and total nitrogen and optimal values.

From Fig. 5 to Fig. 7 shows correlations between T-N, $\mathrm{T}-\mathrm{P}$ nutrient observed values and simulated values about outlet 2, in 2005. From Fig. 8 to Fig. 10 shows correlations between $\mathrm{T}-\mathrm{N}, \mathrm{T}-\mathrm{P}$ nutrients observed values and simulated values about outlet 4 in 2005. As the figures show, calibrated
Table 3 Nutrient parameters and opimal values

\begin{tabular}{|c|c|c|}
\hline Input file & Parameters (Unit) & Corrected values \\
\hline *.bsn & NPERCO (dimensionless) & 0.3 \\
\hline *.bsn & PPERCO $\left(\mathrm{m}^{3} / \mathrm{Mg}\right)$ & 10 \\
\hline *.bsn & PHOSKD $\left(\mathrm{m}^{3} / \mathrm{Mg}\right)$ & 180 \\
\hline *.chm & SOL_SOLP (mg/kg) & 0.05 \\
\hline *.chm & $\mathrm{SOL} \_\mathrm{NO}_{3}(\mathrm{mg} / \mathrm{kg})$ & 0.01 \\
\hline
\end{tabular}

Table 4 Coefficient of determination of total nitrogen and total phosphorus by outlet

\begin{tabular}{c|c|c|c|c}
\hline \multirow{2}{*}{ Classification } & \multicolumn{2}{|c|}{ T-N } & \multicolumn{2}{c}{ T-P } \\
\cline { 2 - 5 } & Outlet 2 & Outlet 4 & Outlet 2 & Outlet 4 \\
\hline \hline Coefficient of Determination $\left(\mathrm{R}^{2}\right)$ & 0.77 & 0.86 & 0.62 & 0.63 \\
\hline
\end{tabular}




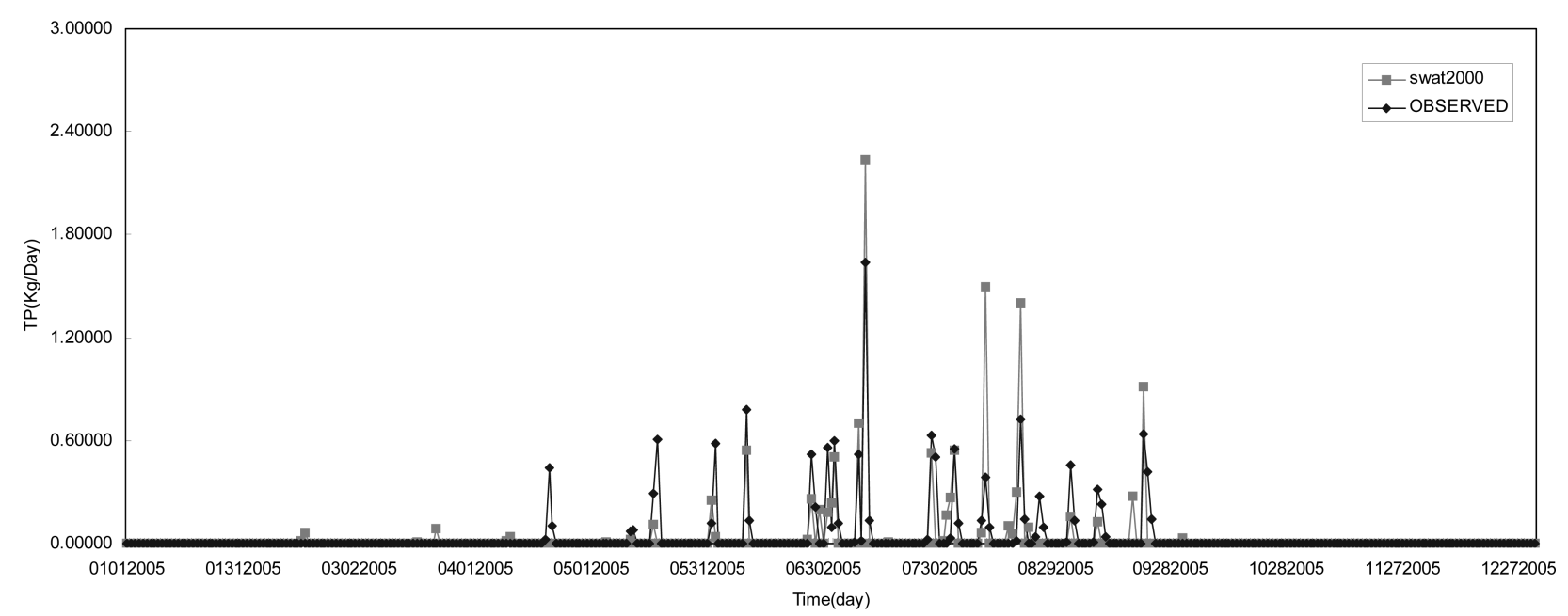

Fig. 6 T-P Simulated and observed values at outlet 2

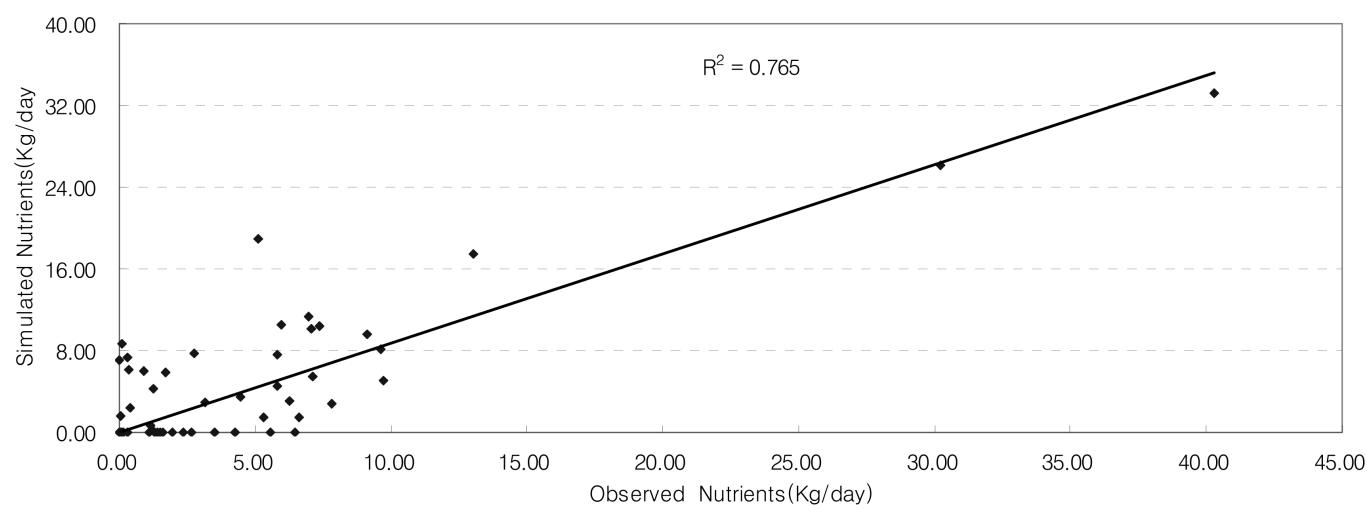

(a) $\mathrm{T}-\mathrm{N}$

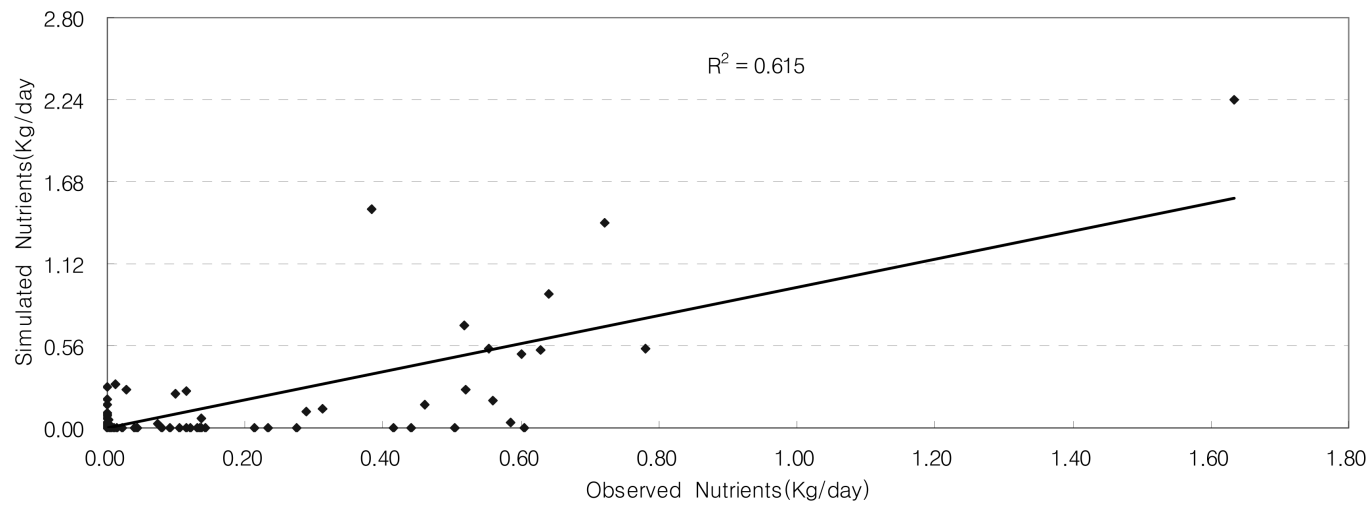

(b) $\mathrm{T}-\mathrm{P}$

Fig. 7 T-N and T-P Simulated and observed values correlations at outlet 2

values were relatively well optimized in close proximity to the observed values.

(3) Validation of Model
For model validation, runoff, $\mathrm{T}-\mathrm{N}, \mathrm{T}-\mathrm{P}$ vaule measured in 2006 were applied and the result shows good correlations between runoff, T-N, T-P observed values and simulated values about outlet 2, 4 in 2006 . 


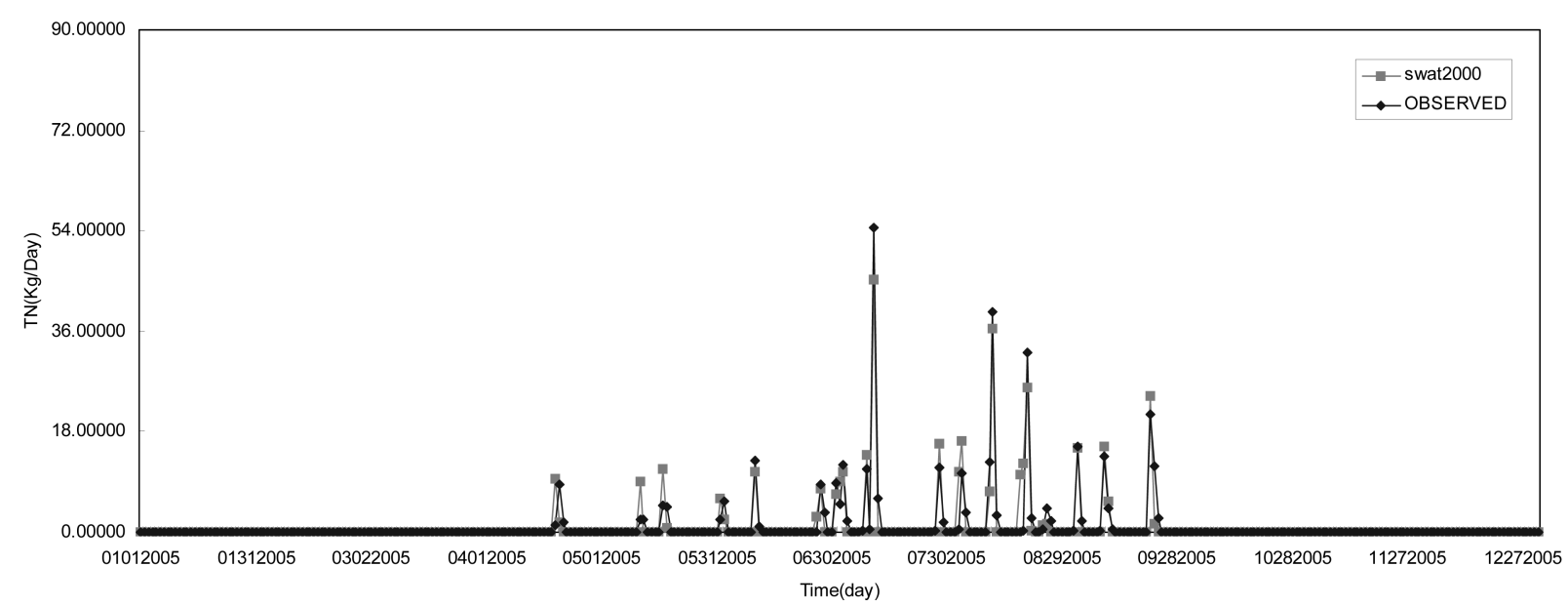

Fig. 8 T-N Simulated and observed values at outlet 4

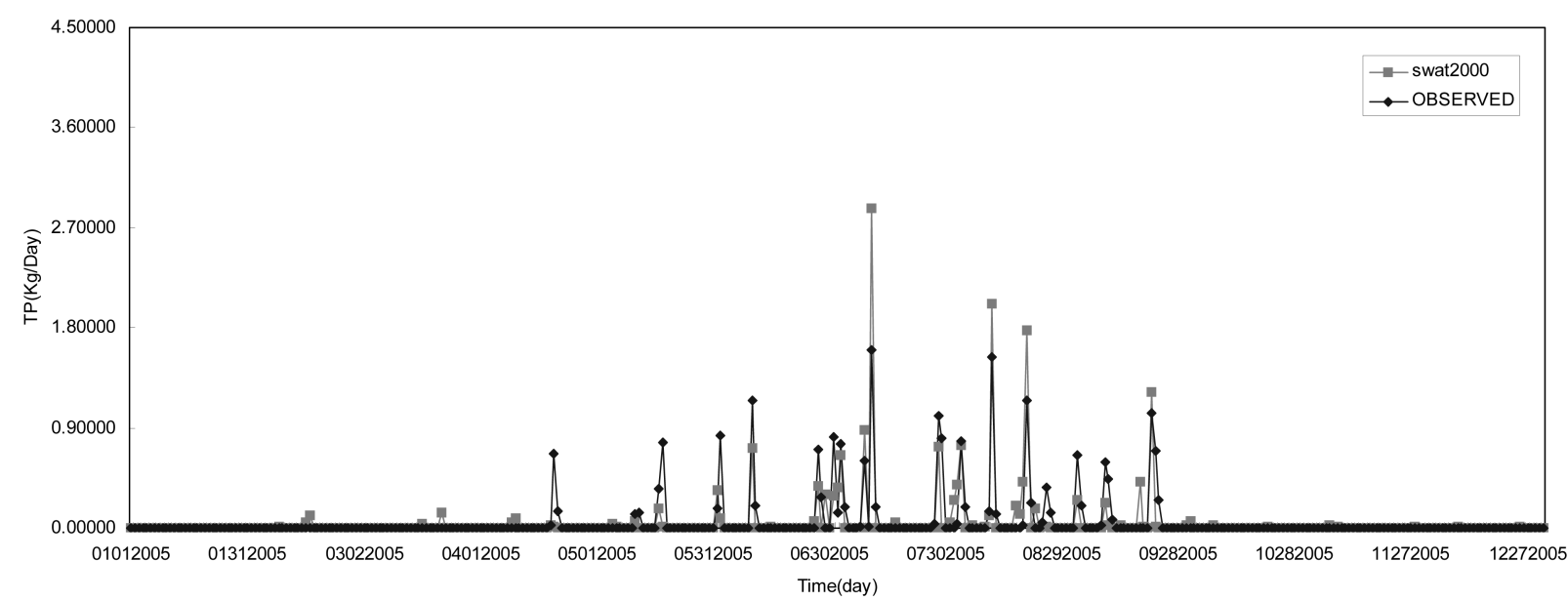

Fig. 9 T-P Simulated and observed values at outlet 4

Table 5 Coefficient of determination of runoff amount by outlet

\begin{tabular}{c|c|c}
\hline Classification & Outlet 2 & Outlet 4 \\
\hline \hline Coefficient of Determination $\left(\mathrm{R}^{2}\right)$ & 0.80 & 0.83 \\
\hline
\end{tabular}

Table 6 Coefficient of determination of total nitrogen and total phosphorus by point

\begin{tabular}{c|c|c|c|c}
\hline \multirow{2}{*}{ Classification } & \multicolumn{2}{|c|}{$\mathrm{T}-\mathrm{N}$} & \multicolumn{2}{c}{$\mathrm{T}-\mathrm{P}$} \\
\cline { 2 - 5 } & Point 2 & Point 4 & Point 2 & Point 4 \\
\hline \hline Coefficient of Determination $\left(\mathrm{R}^{2}\right)$ & 0.77 & 0.86 & 0.62 & 0.63 \\
\hline
\end{tabular}

\section{Long Term Simulation and Result Analysis}

A. Yearly load calculation

Table 7, 8 shows calibrated result of SWAT model and observed T-N, T-P loads. Loads of field and nutrients load calculation set as the difference between outlet 4 and outlet 2 , and in the case of forest area, for nutrients calculation value of outlet 2 was used.

\section{B. Yearly unit area load calculation}

It was divided by forest area and field area respectively and Table 9, 10 shows unit calculation like the following.
C. Load calculation of the past decade through SWAT model

Calibrated parameters through SWAT model and 2005 observed data were applied and for the past decade (1997 2006), at outlet 2 and 4, as Table 11 shows, average loads were calculated.

From 1997 to 2006, through SWAT simulation of the 


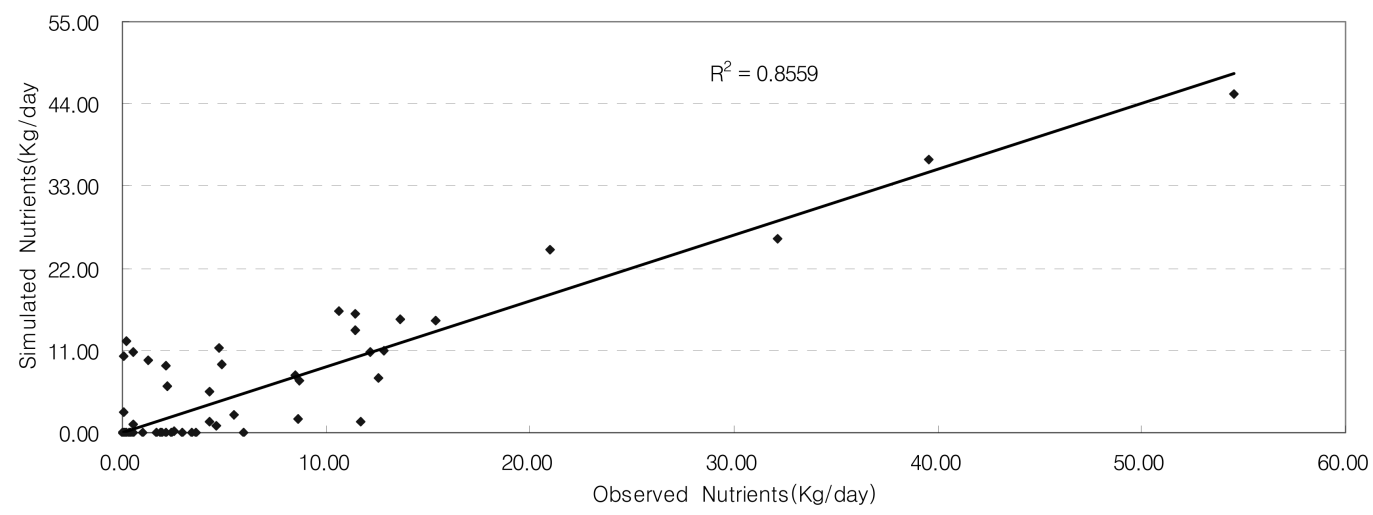

(a) $\mathrm{T}-\mathrm{N}$

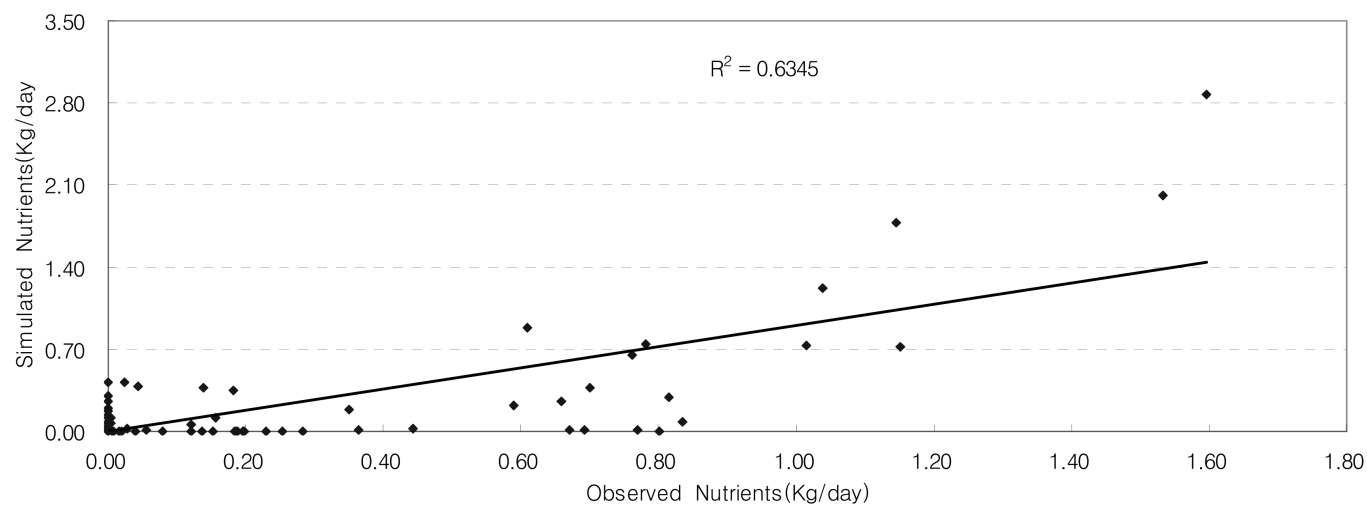

(b) $\mathrm{T}-\mathrm{P}$

Fig. $10 \mathrm{~T}-\mathrm{N}$ and T-P Simulated and observed values correlations at outlet 4

Table 7 Yearly load calculation of observed and simulated values (2005) (Unit : $\mathrm{kg} /$ year)

\begin{tabular}{c|c|c|c}
\hline \multicolumn{2}{c|}{ Precipitation In 2005 } & \multicolumn{2}{c}{$1656.1 \mathrm{~mm}$} \\
\hline \multicolumn{2}{c}{ Classification } & Forest land & Field \\
\hline \multirow{2}{*}{ T-N } & Observed loads & 241.8 & 113.5 \\
\cline { 2 - 4 } & Simulated loads & 251.5 & 96.8 \\
\hline \multirow{2}{*}{ T-P } & Observed loads & 13.8 & 6.7 \\
\cline { 2 - 4 } & Simulated loads & 12.1 & 5.2 \\
\hline
\end{tabular}

Table 8 Yearly load calculation of observed and simulated values (2006) (Unit : $\mathrm{kg} /$ year)

\begin{tabular}{c|c|c|c}
\hline \multicolumn{2}{c|}{ Precipitation In 2006 } & \multicolumn{2}{c}{$977.0 \mathrm{~mm}$} \\
\hline \multicolumn{2}{c}{ Classification } & Forest land & Field \\
\hline \hline \multirow{2}{*}{ T-N } & Observed loads & 96.2 & 74.7 \\
\cline { 2 - 4 } & Simulated loads & 150.5 & 62.5 \\
\hline \multirow{2}{*}{ T-P } & Observed loads & 7.3 & 4.7 \\
\cline { 2 - 4 } & Simulated loads & 5.2 & 2.9 \\
\hline
\end{tabular}

past ten years, nutrient load calculation of sloping field in Bonggok stream watershed were calculated with the average
Table 9 Unit area load calculation of forest area and field area (2005) (Unit : $\mathrm{kg} / \mathrm{km}^{2} \cdot$ day)

\begin{tabular}{c|c|c|c}
\hline \multicolumn{2}{c|}{ Classification } & Forest land & Field \\
\hline \hline \multirow{2}{*}{ T-N } & Observed loads & 2.88 & 14.55 \\
\cline { 2 - 4 } & Simulated loads & 2.99 & 12.41 \\
\hline \multirow{2}{*}{ T-P } & Observed loads & 0.16 & 0.86 \\
\cline { 2 - 4 } & Simulated loads & 0.14 & 0.67 \\
\hline
\end{tabular}

Table 10 Unit area load calculation of forest and field (2006) (Unit : $\mathrm{kg} / \mathrm{km}^{2} \cdot$ day)

\begin{tabular}{c|c|c|c}
\hline \multicolumn{2}{c|}{ Classification } & Forest land & Field \\
\hline \hline \multirow{2}{*}{ T-N } & Observed loads & 1.15 & 9.58 \\
\cline { 2 - 4 } & Simulated loads & 1.79 & 8.01 \\
\hline \multirow{2}{*}{ T-P } & Observed loads & 0.09 & 0.61 \\
\cline { 2 - 4 } & Simulated loads & 0.06 & 0.37 \\
\hline
\end{tabular}

difference of the past ten years of outlet 2 and 4 , and for forest areas' nutrient calculation, the average value of outlet 2 of the past ten years was used. The calculation results showed that load per unit was $3.29 \mathrm{~kg} / \mathrm{km}^{2} \cdot$ day in 
Table 11 Yearly load calculation of the past decade through SWAT model (Unit : kg/year)

\begin{tabular}{c|c|c|c|c|c}
\hline \multirow{2}{*}{ Year } & \multirow{2}{*}{$\begin{array}{c}\text { Precipitation } \\
(\mathrm{mm})\end{array}$} & \multicolumn{2}{|c|}{ Outlet 2} & \multicolumn{2}{c}{ Outlet 4 } \\
\cline { 3 - 6 } & & $\mathrm{T}-\mathrm{N}$ & $\mathrm{T}-\mathrm{P}$ & $\mathrm{T}-\mathrm{N}$ & $\mathrm{T}-\mathrm{P}$ \\
\hline \hline 1997 & 1765.9 & 494.8 & 53.1 & 595.2 & 62.8 \\
\hline 1998 & 2070.0 & 359.5 & 12.2 & 481.8 & 18.8 \\
\hline 1999 & 1455.2 & 265.1 & 6.6 & 343.9 & 11.0 \\
\hline 2000 & 1707.5 & 297.6 & 10.5 & 400.5 & 15.9 \\
\hline 2001 & 828.7 & 143.0 & 2.8 & 178.5 & 5.1 \\
\hline 2002 & 1378.7 & 257.6 & 9.5 & 321.7 & 14.0 \\
\hline 2003 & 1748.9 & 267.0 & 8.8 & 362.1 & 14.1 \\
\hline 2004 & 1496.5 & 235.7 & 7.9 & 327.4 & 12.3 \\
\hline 2005 & 1656.1 & 251.5 & 12.1 & 348.3 & 17.3 \\
\hline 2006 & 977.0 & 150.5 & 5.2 & 213.0 & 8.1 \\
\hline
\end{tabular}

forest area, and load of $\mathrm{T}-\mathrm{P}$ unit area was $0.15 \mathrm{~kg} / \mathrm{km}^{2}$. day. Load per $\mathrm{T}-\mathrm{N}$ unit are in sloping field was 11.15 $\mathrm{kg} / \mathrm{km}^{2} \cdot$ day and load per T-P unit area was $0.70 \mathrm{~kg} / \mathrm{km}^{2}$.

\section{CONCLUSIONS}

In this study, Flowrate, $\mathrm{T}-\mathrm{N}$ and $\mathrm{T}-\mathrm{P}$ were measured for the SWAT calibration and validation from 2005 to 2006 in Bonggok watershed which located at Banpo-Myeon, Gongju City, Chungcheongnam-DO of the Republic of Korea as a representative forest area including reclamated sloping cropland. and then unit area load of $\mathrm{T}-\mathrm{N}$ and $\mathrm{T}-\mathrm{P}$ was estimated from sloping cropland and forest

As the result of implementing calibration and validation of SWAT model by using daily runoff discharge data which were measured during 2005 2006, Coefficient of Determination $\left(\mathrm{R}^{2}\right)$ showed values of $0.80 \sim 0.83$ and Coefficient of Detemination $\left(\mathrm{R}^{2}\right)$ for $\mathrm{T}-\mathrm{N}$ and $\mathrm{T}-\mathrm{P}$ showed values of $0.62 \sim 0.86$. And then SWAT simulation was performed from 1997 to 2006 with optimal parameters determined through calibration process so as to estimate long-term unit area load from sloping cropland and forest in experimental watershed. As the result of calculating unit area load for $\mathrm{T}-\mathrm{N}$ and $\mathrm{T}-\mathrm{P}$ for the past 10 years with SWAT model, $\mathrm{T}-\mathrm{N}$ unit area load from forest was $3.29 \mathrm{~kg} / \mathrm{km}^{2}$. day and T-P unit area load was $0.15 \mathrm{~kg} / \mathrm{km}^{2}$. day and T-N unit area load from sloping cropland was $11.15 \mathrm{~kg} / \mathrm{km}^{2} \cdot$ day and T-P unit area load was $0.70 \mathrm{~kg} / \mathrm{km}^{2}$. day. It showed that a little smaller than the unit area load suggested by calculation based on short-term measured data, it was judged that we can manage more efficiently nonpoint pollution sources in target watershed by using average annual discharge load which was estimated with long-term simulation data of SWAT model.

\section{REFERENCES}

1. Arnold, J. G., Srinivasan, R., Muttiah, R. S. and J. R. Williams, 1998. Large-area hyDrologic modeling and assessment: Part 1. Model development. Journal of American Water Resources Association 34(1): 73-89.

2. An, J. H., and H. D. Lee, 2001. Estimation of nonpoint pollution source original unit and generated amount in Paldang waterworks basin using discharge loads of rainfall, Journal of Korean Society of Water Quality 17(3): 313-326 (in Korean).

3. Cho, J. P., 1998. Application of agricultural industry nonpoint source of complex landuse characteristics to rural area river valley. Master's thesis of Seoul National University (in Korean).

4. Choi, J. D., and J. E. Yang, 2002. Evaluation of discharge of nonpoint pollution source in agricultural industry small basin depending on land use. Journal of Korean Society of Water Quality 18(1) : 47-55 (in Korean).

5. Choi, J. Y. and E. S. Shin, 1998. Research on management method of nonpoint pollution source in rural areas. Korean Institute of Policy Evaluations (in Korean).

6. Di Luzio, M., Srinivasan, R. and J. G. Arnold. 2001. Soil and Water Assessment Tool ArcView Interface Maunal, Version 2000. Temple, TX. Blackland Research Center Texas Agricultural Experiment Station.

7. Di Luzio, M., Srinivasan, R. and J. G. Arnold, 2002. Integration of watershed tools and SWAT model into BASINS, Journal of American Water Resources Association 38(4): 1127-1141.

8. Kang, M. S., 2002, System development of total pollution amount simulation using artificial nerve network remote search method and nonpoint pollution model, Master's thesis of Seoul National University (in Korean).

9. Moon, J., Srinivasan, R., and J. H. Jacobs, 2004. Stream 
Flow Estimation Using spatially Distributed Rainfall in the Trinity River Basin, Texas. Transaction of The ASAE 47(5): 1445-1451.

10. Neitsch, S. L., J. G. Arnold, J. R. Kiniry, and J. R. Williams., 2001. Soil and Water Assessment Tool Theoretical Documentation, Version 2000. Temple, TX. Blackland Research Center, Texas Agricultural Experiment Station.

11. Neitsch, S. L., J. G. Arnold, J. R. Kiniry, and J. R. Williams., 2001. Soil and Water Assessment Tool User's Manual, Version 2000, Temple, TX. Blackland Research Center Texas Agricultural Experiment Station.
12. Park, J. H., D. S. Gong, and K. S. Min, 2008. Characteristics of reaching loads of point-nonpoint of upstream of Paldang lake centering on the subjects of Namhan river $\cdot$ Kyungan stream water system. Journal of Korean Society of Water Quality for water quality preservation 24(6): 750-757 (in korean). 